\title{
THEOLOGY AND SPIRITUALITY: STRANGERS, RIVALS, OR PARTNERS?
}

\author{
Sandra M. Schneiders, I.H.M. \\ Jesuit School of Theology \\ Graduate Theological Union, Berkeley
}

\begin{abstract}
After tracing the history of the term "spirituality" and the discipline of spirituality up to the mid-twentieth century, this article describes the contemporary understanding of spirituality as lived religious experience and of the academic discipline which studies this subject. This phenomenology of the discipline grounds a position on the relationship between lived spirituality and theology on the one hand, and the academic disciplines of spirituality and theology on the other.
\end{abstract}

\section{Introduction: The Present Situation}

\section{The "Spirituality Phenomenon"}

Just as the biblical and liturgical renewals dominated the Catholic scene in the 1950's and 1960's, spirituality has dominated the Catholic consciousness since the 1970's and shows little sign of disappearing from the center of concern in the foreseeable future. The grip of spirituality on the imagination and energies of Christians in general and Catholics in particular is baffling, from a logical point of view, because of the widespread confusion about the very meaning of the term, not to mention the more complicated question of its relationship to other activities and fields of study. Spirituality is, in a sense, a phenomenon which has not yet been defined, analyzed, or categorized to anyone's satisfaction. No doubt this essay will not rectify that situation but perhaps it can make a modest contribution toward sorting out the problems, marshaling the available resources, and suggesting some working hypotheses which can be tested against the experience of both believers interested in spirituality as personal experience and scholars working in the academic discipline of spirituality.

Sandra M. Schneiders, I.H.M., is associate professor of New Testament Studies and Christian Spirituality at the Jesuit School of Theology/Graduate Theological Union (Berkeley, CA 94709). She serves on the editorial boards of Horizons, Catholic Biblical Quarterly, Biblical Theology Bulletin, and the Paulist "Classics of Western Spirituality." Her articles have appeared in Theological Studies, Catholic Biblical Quarterly, Chicago Studies, Spirituality Today, and elsewhere. She currently serves on the staff of the Institute for Spirituality and Worship at JSTB and is facilitator of the doctoral program in Christian Spirituality at the GTU. 
Spirituality, as the term is used today, did not begin its career in the classroom but among practicing Christians, mostly Catholics, whose religious experience intensified in the wake of Vatican II. For some, spirituality had to do primarily with prayer. Those who became involved in the Charismatic Renewal, in the retreat movement, and in the House of Prayer movement typify this focus in spirituality.

For a second group of people spirituality had a slightly wider connotation, having to do not just with prayer but with an intensified faith life which embraced the whole of one's daily experience. The Cursillo and Marriage Encounter, among others, were intense, shortterm experiences designed to launch their participants on faith-filled journeys in the context of their everyday lives. Many of these people, like those who had made directed retreats, sought ongoing spiritual direction in order to foster the deepened spiritual lives inaugurated by these intense religious awakenings.

A third group of people took an even wider approach to spirituality. For these, spirituality was concerned not just with prayer and the intensification of the faith dimension of daily life, but with the whole of personal experience, especially those elements of experience which Catholic theology and morality had tended to denigrate, i.e., the body and the emotions. Such people talked of holistic spirituality or bodily spirituality and emphasized the integration of the material dimensions of humanity into one's approach to Christian living.

Finally, there were those who focused on the implications of Christian commitment for social and political life. These people understood the positive alignment of self with the purposes and processes of creation, the protection of the environment, the struggle for justice, and the building of a better world to be the proper sphere of spirituality.

Although these four approaches to spirituality did not develop in strict chronological order it does seem to have been the case that the term was first used in a rather restricted way to talk about personal religious experience in prayer and was gradually widened in scope to include the entirety of the individual's life and eventually the societal and global setting which influenced and was influenced by that personal experience. It is important for our purposes, however, to be aware that all four of these connotations are operative when the term spirituality is used today and it is not always clear which is in the forefront, nor are all in agreement that the term is properly used in each and all of these ways.

\section{Widening the Horizons of Spirituality}

The situation has been further complicated by the fact that spirituality has ceased to be an exclusively Catholic term. Protestants, who had long been suspicious of the term "spirituality" because of its connection with enthusiasm and mysticism, and who had preferred such terms as 
"devotion," "piety," and "perfection" for speaking of the interior life, ${ }^{1}$ began, in the context of the ecumenical exchanges inaugurated by Vatican II, to use the heretofore Catholic term. Not only did they learn Catholic meanings, but they contributed from their own traditions to Catholic understanding of the interior life and its exterior ramifications. But the dialogue has not remained intra- or inter-Christian. Jews, who have long used the term mysticism for the more intense pursuit of the interior life, have begun to use the more comprehensive term "spirituality" and to apply it to the ordinary but serious pursuit of holiness according to the Law as well as to the more strictly contemplative experience. Thus, they have borrowed not only a term but an approach to religious experience and, at the same time, facilitated their participation in the conversation about religious growth that is developing in Christian circles. And, of course, the interest of Christians in eastern religions, particularly in Buddhism, has been essentially a fascination with eastern spirituality. Finally, the term "spirituality" has begun to be used for life orientations which are non-religious or even anti-religious. One hears talk of feminist spirituality, Black spirituality, and Marxist spirituality. Again, we are witnessing an expansion of the term from a strictly Roman Catholic usage in which most of the terminology was fairly standardized, to an ecumenical but still Christian usage in which some terms are unfamiliar or are used in unfamiliar ways, to a usage which includes non-Christian religious experience which must be grasped by analogy through serious and open dialogue, and even to a non-religious usage whose meaning is anything but clear.

\section{Academia Enters the Picture}

As might have been expected, this burgeoning interest in spirituality has provoked intense interest in the academy. Religious colleges and universities, mostly Catholic at the beginning, tried to meet the needs of these newly committed believers who were searching for resources to nourish and foster their spirituality. One such resource was the "renewal program" which usually had a directly practical aim of supplying theological updating, nourishing liturgical and community experience, workshops on issues and problems of the spiritual life such as prayer, emotional growth, and personal relationships, and some form of individual spiritual guidance such as directed retreats and spiritual direction.

A second contribution of the academy was programs designed to form people who could assist others in the spiritual life, notably formation personnel for religious orders and seminaries and spiritual di-

'See Jon Alexander, "What do Recent Writers Mean by Spirituality?" Spirituality Today 32 (1980), 247-48. 
rectors. Such programs usually included courses on the history of spirituality, theology, psychology, spiritual direction, religious and priestly spirituality, prayer, and ministry. In other words, there was a felt sense for the "content" of spirituality, what it was about, even though there was little recourse to the classical textbooks on spirituality of the nineteenth and early twentieth centuries. People seem to know, intuitively, that whatever spirituality means to the twentieth-century Catholic it is something different from what most religious had studied in the novitiate in the works of Tanquerey, de Guibert, Rodriguez, or even Gustave Thils and Columba Marmion.

Finally, and most recently, we are witnessing the prolonged and difficult birth, within the halls of the academy, of a new scholarly discipline called spirituality. A few major centers of theological learning have doctoral programs in spirituality, programs which are neither renewal programs nor practical masters, but genuine academic research programs whose purpose is to study spirituality itself and to prepare those who will carry the discipline into the future. ${ }^{2}$

Needless to say, one of the most urgent and difficult problems facing this new discipline is the delineating of its own contours within the geography of academic theology and the defining of its subject matter and methodology. Those involved in the field have no doubt about the validity of their enterprise nor about its future but their enthusiasm is not universally shared, especially by the guardians of the academic status quo. In this respect, spirituality is, in the theological world, where sociology was among the human sciences half a century ago. The number and quality of scholars in the field is increasing, not only by the "conversion" of scholars from other branches of theology and religious studies who have discovered that the interests which brought them into their fields are being more directly addressed in this new field called spirituality, but also by the graduation each year of young scholars with Ph.D.s in spirituality.

The number of scholarly publications is increasing rapidly. In the original edition of The Catholic Encyclopedia (1913-22) ${ }^{3}$ there were no articles under the heading "spirituality." In the current edition of The New Catholic Encyclopedia 4 there are eight articles with "spirituality" in their titles and thirteen references to spirituality in the index. The monumental Dictionnaire de Spiritualité begun in 1937 continues its slow journey toward completion, the volume covering the letter "P"

${ }^{2}$ Besides the program at Institut Catholique in Paris and the Instituto di Spiritualità at the Gregorian University in Rome there are several doctoral programs in the United States, notably at Fordham University in New York City and at the Graduate Theological Union in Berkeley, California.

${ }^{3}$ The Catholic Encyclopedia, ed. C. G. Herbermann et al. (New York: Encyclopedia Press, 1913-22).

${ }^{4}$ New Catholic Encyclopedia, ed. Catholic University of America staff (New York: McGraw-Hill, 1967-79). 
having appeared in $1984 .{ }^{5}$ The sixty-volume Paulist Press project entitled "Classics of Western Spirituality" begun in 1978 is well advanced and is making the major texts in spirituality of the Roman Catholic, Orthodox, Protestant, Jewish, Muslim, and Native American traditions available in excellent critical English-language editions. ${ }^{6}$ The Westminster Dictionary of Christian Spirituality ${ }^{7}$ appeared in 1983. This year Crossroad will bring out the first volumes, those dealing with Christian spirituality, of its twenty-five volume Encyclopeida of World Spiritualities. The appearance of these major research and reference tools as well as of numerous scholarly monographs, much middle-level writing, and the ongoing publication of a number of scholarly and popular journals in the field testifies to the growth of a new discipline while pointing directions to answers to some of the questions with which any emerging discipline must deal.

Before we can address some of those questions, and in particular the question of the relationship of spirituality to theology, it will be useful to trace briefly two historical trajectories. First, we will look at the word "spirituality" in order to discern, if possible, to what the word has referred throughout Christian history. In other words, our concern will be with the reality designated by the term and the continuity or discontinuity of that reality with what the term designates today. Secondly, we will trace the history of the discipline of spirituality to see whether the study of this reality as it has been carried on in the past bears any relationship to the newly developing discipline. Throughout our investigation we will have to bear constantly in mind the distinction between spirituality as lived experience and spirituality as the academic discipline which studies that experience.

\section{History of the Term "Spirituality"}

The Christian Etymology of the Term"

The adjective "spiritual" from which the substantive "spirituality" is derived is a Christian neologism, coined apparently by St. Paul to describe that which pertained to the Holy Spirit of God. The theology of the

${ }^{5}$ Dictionnaire de Spiritualité Ascétique et Mystique, ed. M. Viller (Paris: Beauchesne, 1937-84).

"The series began under the general editorship of Richard Payne and is being carried forward by John Farina.

${ }^{\top}$ Westminster Dictionary of Christian Spirituality, ed. Gordon Wakefield (Philadelphia: Westminster, 1983).

${ }^{8}$ The history of the term "spirituality" was studied in great detail by Lucy Tinsely, The French Expression for Spirituality and Devotion: A Semantic Study Studies in Romance Languages and Literatures, 47 (Washington, DC: Catholic University of America Press, 1953).

"See Jean Leclercq, augmenting Tinsley's work, in an article entitled “" 'Spiritualitas'," Studi Medievali 3 (1963), Ser. 3, 279-96. In this section of the paper I am much indebted to Leclercq. 
Spirit began to develop in Old Testament reflection on the breath or ruah of Yahweh and was further developed in New Testament reflection on the pneuma or Spirit which almost immediately came to be understood as the Spirit of the risen Christ. ${ }^{10}$ Paul used the adjective "spiritual" for objects which were somehow under the influence of or were manifestations of the Spirit of God, the Holy Spirit. Thus he spoke of the Law (Rom 7:14), truth (1 Cor 2:13), gifts or charisms (1 Cor 12:1), blessings (Eph 1:3), hymns or songs (Eph 5:19), and understanding (Col 1:9) as spiritual. But most interestingly, in 1 Cor 2:14-15, he contrasted the "spiritual person" (pneumatikos anthrôpos) with the "natural person" (psychikos anthropos). His usage makes it clear that he is not contrasting a person with a human spirit in the sense of soul, that is, a living person, with one who lacks a soul, that is, a dead person. Both the spiritual and the unspiritual person are alive, possessed of body and soul. The spiritual person is one who is indwelt by the Holy Spirit of God. The use of spirit/spiritual in contrast to matter/material did not develop until many centuries later. So far we have ascertained that the word "spirituality" has its origin in Christian usage and that its root reference is to the presence and influence of the Holy Spirit.

\section{Development of the Word up to the Twentieth Century}

From the patristic period through the eleventh century the meaning of the word "spirituality" changed little. It referred quite consistently to life according to the Holy Spirit and all the activities of that life. ${ }^{11}$ In the period of the desert fathers and mothers the term was sometimes used in a kind of superlative sense to speak of the striking holiness of those in whom the life of the Spirit was especially vividly manifested, particularly by the gift of intuitive penetration of the scriptures and the capacity to search and guide the human heart. But, in general, the term basically referred to that which was not due to nature but to grace, that which was characterized by the presence and activity of the Holy Spirit.

By the twelfth century, under the influence of philosophical developments in theology, we see the first use of the term "spiritual" to designate the intellectual creature in contrast to non-rational creation. In other words, spiritual is here contrasted to material. By the thirteenth century this profane, philosophical meaning stood side by side with the older religious meaning. They were joined by a third meaning, a purely juridical one, according to which spirituality was the contrary of temporality and designated the clergy and/or ecclesiastical goods. From the thirteenth to the sixteenth century the juridical usage seems to have been

\footnotetext{
${ }^{10}$ For a brief summary of the relevant biblical material, see Josel Sudbrack, "Spirituality," Sacramentum Mundi (New York: Herder and Herder, 1970), 6:148-49.

"See Jean Leclercq, "Introduction," tr. Monique Coyne, The Spirituality of Western Christendom, ed. E. Rozanne Elder (Kalamazoo, MI: Cistercian Publications, 1976).
} 
the most common. The term in its philosophical and theological senses was seldom used.

In the seventeenth century the religious term suddenly reappeared and became the focus of much controversy. Spirituality in its positive sense referred to the interior life, especially to the affective relationship with God. The seventeenth century was the golden age, so to speak, of spirituality but alongside the orthodox and healthy developments there were numerous less than orthodox developments of an enthusiastic and quietistic nature. Sometimes, therefore, the term "spirituality" was used pejoratively in contrast to the term "devotion" which placed a proper emphasis on human effort in the spiritual life. But, in general, the word "spirituality" was used to denote everything that pertained to the interior life, especially to the quest for perfection above and beyond the requirements of ordinary Christian life whether that quest was orthodox or suspect.

By the eighteenth century the distinction between the ordinary Christian life and the life of perfection had given rise to a lively debate which itself furthered the development of the discipline of spirituality as we shall see later. The debate centered on the continuity or discontinuity between the life of ordinary virtue and the mystical life, and was especially concerned over whether all Christians or only some are called to the mystical life. This debate was still being pursued in the first decades of our own century until it was finally, it would seem, settled by Vatican II which declared that all Christians are called to one and the same holiness. ${ }^{12}$ However, the sharp distinction that for centuries has been drawn between the ascetical life and the mystical life has encouraged the use of the more comprehensive term "spirituality" to refer to the spiritual life as a whole in all of its stages beyond the most rudimentary observance of the commandments. In other words, the term tended to include all stages of the pursuit of perfection in the interior life through spiritual exercises and the practice of virtue above and beyond what is required by the commandments as well as the mystical life which crowned this pursuit in the case of some people.

In the nineteenth century, while the basic denotation of the term remained substantially the same as it had been since its revival in the seventeenth century, the emphasis fell more clearly upon the spiritual life as lived, that is, upon the experiential and practical implications of the word. Authors such as Pierre Pourrat who wrote the first comprehensive history of spirituality, ${ }^{13}$ stressed this aspect of spirituality and the consequent need for the study of the spiritual life, especially by the clergy whose task was to guide the faithful in the ways of perfection. The

${ }^{12} \mathrm{Cf}$. Lumen Gentium V:40-41.

${ }^{13}$ Pierre Pourrat, Christian Spirituality, 4 vols., tr. W. H. Mitchell and S. P. Jacques (Westminster: Newman, 1953-55 [1927]). 
academic discipline of spirituality in the formal sense was born in the nineteenth century.

To summarize our findings from this rapid historical survey we can say that the word "spirituality" is originally a Christian term. Until the late nineteenth century when it was occasionally used by some of the free churches it was an exclusively Roman Catholic term more current in France than elsewhere. For all intents and purposes the term retained its original reference to life according to the Holy Spirit but this life tended to be understood less as the common pursuit of all Christians and more as the special enterprise of souls seeking perfection. The seeking of perfection was understood as ever more individualized and interiorized and centered more exclusively in the practice of specialized spiritual exercises thus requiring more intensive spiritual guidance by trained directors. The emphasis was on affectivity and thus the word took on a highly experiential tone. The juridical use of the word disappeared completely while the philosophical meaning remained current in Scholastic circles but had little influence elsewhere. As we will see, this juxtaposition of the philosophical and the religious meanings is helpful for understanding our own situation in which the term "spirituality" is by no means an exclusively Roman Catholic or even Christian term and by no means always involves reference to the Holy Spirit or to life according to the Spirit.

\section{History of the Discipline of Spirituality}

From the First to the Nineteenth Century

Until the high Middle Ages the study of theology was a unitary endeavor to which the modern divisions into dogmatics (with its subdivisions of theology, christology, and ecclesiology), moral theology (with its specializations into general and special, personal and social), church history, and biblical studies was entirely foreign. Much of what was called theology at that time would today be called biblical theology and/or biblical spirituality, that is, it was exegetically based interpretation of scripture for the purpose of understanding the faith and living the Christian life.

In the thirteenth century Thomas Aquinas divided his great theological synthesis, the Summa Theologiae, into three parts: Part I dealing with God as first principle; Part II dealing with God as last end of creation including humans; and Part III on the Incarnate Word as the way to the end. In effect, he established the divisions of theology as they would be understood until Vatican II: dogma, moral, and christology. Thomas put most of what he had to say about the Christian life in Part II of the Summa, thus effectively establishing what would later be called spiritual theology or spirituality as a subdivision of moral theology. And thus the situation has remained until very recent times. 
It must be remembered that throughout this long period, and after it until the early twentieth century, a great deal of highly valuable writing on the spiritual life was produced. Sometimes these were works of formal theology, but more often they were not. The literature of spirituality was written in extremely diverse genres. There were monastic and religious rules, commentaries on scripture, sermons and conferences, poems and hymns, spiritual treatises, biography and autobiography. Some of this writing was done by professional theologians such as Augustine, Bernard, and John of the Cross. But much of it was also done by people who were not, or could not be, theologians in the professional sense of the word, people like the desert fathers and mothers, Benedict, Francis of Assisi, the author of The Cloud of Unknowing, Catherine of Siena, Julian of Norwich, Teresa of Avila, Thérèse of Lisieux, Thomas Merton, and Dorothy Day. And, of course, many of the great classics were written by Orthodox theologians and non-theologians such as Gregory Palamas and Symeon the New Theologian as well as by Protestants such as Jacob Boehme, William Law, John Wesley, and Jonathan Edwards. Some of these writers, at least among the Catholics, referred to their works as "spiritual theology" or "mystical theology" but often enough they gave no such designations. In any case, what these great masters and mistresses of the spiritual life wrote was not part of what was taught in the schools under the heading of "theology." And when spiritual writers did make explicit their theological presuppositions they invariably did so in Scholastic terms even though they sometimes proceeded to write in quite other terms, usually derived from their own mystical experience.

In summary, then, the real history of spirituality as the subject of disciplined reflection and exposition has yet to be written because the classics of this tradition developed largely outside the schools while what was taught in the schools concerning the spiritual life was meager and highly formalized. In fact, the discipline whose subject matter was the spiritual life was first named in 1655 by a Polish Franciscan named Dobrosielski who called the branch of dogma dealing with the spiritual life "ascetical theology."

In the eighteenth and nineteenth centuries, because of the intense interest in the life of perfection that had developed in the preceding century and the debates that it had generated, the spiritual life became an object of study and teaching. By this time the vocabulary of this science, described as the "science of the life of perfection," became stabilized. The field was called "spiritual theology," the science which studied the spiritual life as it was lived by those who had progressed beyond the mere keeping of the commandments. This science has two subdivisions: "ascetical theology" which studied the life of perfection up to the beginning of passive mystical experience; and "mystical theology" which studied that life from the beginning of passive mystical experience to its 
culmination in the most perfect union possible this side of the Beatific Vision.

\section{The Early Twentieth Century}

The textbooks in use in seminaries during the first decades of the twentieth century represent the final development of the discipline prior to our own era. A typical and widely used text was that of Adolphe Tanquerey published in $1930 .{ }^{14}$ In it the author states clearly his conviction that "Dogma is the foundation of Ascetical Theology.... This treatise then is first of all doctrinal in character and aims at bringing out the fact that Christian perfection is the logical outcome of dogma, especially of the central dogma of the Incarnation." 15

Tanquerey was equally clear about the proper object of this discipline. "It is the perfection of the Christian life that constitutes the proper object of ascetical and mystical theology." ${ }^{16} \mathrm{He}$ situated spiritual theology in relationship to dogmatic and moral theology as a branch of theology distinct from both whose proper object was the perfection of Christian life. Founded in dogma, spiritual theology directs the truths of dogma toward practice. It is comprised of three parts: the speculative which consists in the dogmatic explanation of Christian life; the practical which seeks out the means to develop this life; and the art which consists in applying the principles to individual souls. ${ }^{17}$ As would be expected Tanquerey considered revelation (scripture and Tradition) and rational knowledge (faith and experience) to be the sources of this branch of theology. The method proper to spiritual theology was both deductive and inductive, although it is clear that Tanquerey considered the deductive moment the most important, for unless universal principles governed the study it could not pretend to be a true science, a genuine branch of the science of theology. Thus, he divided his classic work on the spiritual life into two parts: principles (the doctrinal section) and application of principles (the psychological and descriptive section). ${ }^{18}$

Pierre Pourrat, who authored the first modern history of spirituality, expressed basically the same conception of the discipline of spirituality:

Spirituality is that part of theology which deals with Christian perfection and the ways that lead to it. Dogmatic Theology teaches what we should believe, Moral Theology what we should do or not do... and above them both, though based upon them both, comes Spirituality or Spiritual Theology.

${ }^{14}$ Adolphe Tanquerey, The Spiritual Life: A Treatise on Ascetical and Mystical Theology, tr. H. Branderis (2nd rev. ed.; Tournai: Desclee, 1930).

${ }^{15}$ Ibid., p. vii.

${ }^{16}$ Ibid., p. 1.

${ }^{17}$ Ibid., p. 5.

${ }^{18}$ Ibid., pp. 5-26. 
This, again, is divided into Ascetic Theology and Mystical Theology. ${ }^{19}$

Although Pourrat claimed that spiritual theology (note, he used this term interchangeably with spirituality) was superior to both dogma and moral the "superiority" was somewhat akin to that of the Victorian wife. Placed on a pedestal and extolled for her superior worth she was, nevertheless, not taken seriously in the affairs of the world nor allowed to participate even as an equal, much less a superior, in the important business of life. So with spiritual theology. Although extolled for its supreme importance as the science of the saints, spirituality was seldom considered an important, much less essential, element in the seminary curriculum. "Real" theology was dogma and moral just as "real" humans in the Victorian era were men.

In summary, the first half of the twentieth century was a period of theoretical stability in regard to the discipline of spirituality. The field was usually called "spiritual theology" and was understood to be a distinct branch of theology. It was, in practice, subordinate to dogmatic theology from which it derived its principles and a subdivision of moral theology which dealt with what was of obligation in the Christian life while spiritual theology dealt with what was supererogatory. Spiritual theology itself was further subdivided into two parts: ascetical theology which dealt with the stages of the life of perfection prior to infused contemplation and mystical theology which dealt with the final stages of the contemplative life. While most scholars in the field agreed on the general outline, basic content, and method of the discipline, they were divided by the question of the place of mysticism in the subject matter. The debate, inherited from the seventeenth century, centered on the subject of the continuity or dicontinuity of the mystical state with previous states and with the universality of the call to the highest states of contemplation. Tanquerey was a proponent of the discontinuity position and Reginald Garrigou-Lagrange of the continuity position. ${ }^{20}$ One of the consequences of the perspective which saw all states of the spiritual life as parts of a continuous whole was the growing preference for the more comprehensive term "spirituality" as the name for the discipline which studied the whole of this life, and a tendency to consider morality a predisposition for the life of perfection rather than the latter as a nonnecessary development of the former.

During this same period there was an interesting reflection of this more comprehensive approach in the literature of the field. In the Elenchus Bibliographicus of the Ephemerides Theologicae Lovanienses in 1924 there was a subheading: "Theologica Ascetica et Mystica” under

${ }^{19}$ Pourrat, Christian Spirituality, 1:v.

${ }^{20}$ Reginald Garrigou-Lagrange, The Three Ages of the Interior Life, 2 vols., tr. T. Doyle (New York: B. Herder, 1948). 
the main heading "Theologia Moralis." By 1951 "Theologica Ascetica et Mystica" had become a section in its own right. And in 1968 this section had, at its head, a subheading "De Spiritualitate in Genere." During the same period various periodicals on the spiritual life began to change their titles to include the term "spirituality" ${ }^{21}$ and to upgrade the academic quality of their articles. A number of new journals in spirituality appeared, such as Studia Mystica in 1978, and major theological journals such as Horizons and Downside Review began to publish serious studies in spirituality. Thus, by the 1950's a major change had begun in the field of spiritual theology. Within the twenty years that followed, a period which coincided with Vatican Council II and the rapid transformation of theology from a dogmatic to a critical sense, spiritual theology would be transformed into spirituality, a new discipline clearly distinct from its seminary predecessor. Our concern now is with the character of this new discipline and its relationship with theology.

\section{Phenomenology of the Contemporary Discipline of Spirituality}

The Contours of the Problem

The attempt to describe or define the contemporary academic discipline of spirituality so as to discern its relationship with theology involves us in two distinct but related questions. The first has to do with the subject matter of spirituality, with that which is the object of study of the discipline. In other words, our first question is "What is spirituality?" as a human phenomenon? What are people speaking about when they talk about spirituality? The second question has to do with the kind of academic discipline which studies whatever it is that spirituality is.

Perhaps a good starting point for arriving at a working definition of spirituality as human phenomenon is to say what spirituality is not.

First, as noted earlier, and in contradistinction to what we have seen to be the case historically, spirituality is no longer an exclusively Roman Catholic phenomenon. In fact, it is not even an exclusively Christian phenomenon. People speak intelligibly of Buddhist, Native American, or African spirituality. Some would maintain that spirituality is not even necessarily theistic or religious.

Second, spirituality today is neither dogmatic nor prescriptive. It does not consist in the application to concrete life of principles derived from theology. Spirituality is understood as the unique and personal response of individuals to all that calls them to integrity and transcendence.

Third, spirituality is not concerned with "perfection" but with growth, and consequently it is not the concern of a select few but of

${ }^{21}$ Most notably, Revue d'ascétique et de mystique which began publication in 1920 changed its name to Revue d'Histoire de la spiritualité in 1972. 
everyone who experiences him or herself drawn toward the fullness of humanity.

Fourth, spirituality is not concerned solely with the "interior life" as distinguished from or in opposition to bodily, social, political, or secular life. On the contrary, spirituality has something to do with the integration of all aspects of human life and experience.

In short, people speaking of spirituality today are talking about something quite different from that which was under discussion in the volumes of Tanquerey and Pourrat. No doubt the subject matter of earlier usages of the term would be included in the subject matter of today's term but the latter is much broader in every sense of the term.

However, stating what spirituality is not is much easier than saying what it is and this precisely because the boundaries of the term have expanded so much. Jon Alexander, in a recent article, after surveying the definitions of spirituality offered by such writers as Carolyn Osiek, Raymundo Panikkar, Hans Urs von Balthasar, John Macquarrie, and Shirley Guthrie, concluded that the term is being used today in an experiential and generic sense. ${ }^{22}$ While I have some reservations about the accuracy of the second characterization I am in complete agreement that, whatever the term means today, it denotes experience. The question is, what kind of experience is spirituality?

\section{The Subject Matter of the Discipline}

Perhaps a useful way to begin our investigation of this question is to list a few of the definitions of spirituality offered by modern authors, Catholic and Protestant:

Panikkar: "one typical way of handling the human condition"23

Macquarrie: "fundamentally spirituality has to do with becoming a person in the fullest sense",

Wakefield: "a word ... to describe those attitudes, beliefs, practices which animate people's lives and help them to reach out towards super-sensible realities" 25

Hardy: "spirituality is that attitude, that frame of mind which breaks the human person out of the isolating self. As it does that, it directs him or her to another in relationship to whom one's growth takes root and sustenance",26

\footnotetext{
${ }^{22}$ Alexander, "What do Recent Writers Mean?" pp. 251-52.

${ }^{23}$ Raymundo Panikkar, The Trinity and the Religious Experience of Man: IconPerson-Mystery (Maryknoll, NY: Orbis, 1973), p. 9.

${ }^{24}$ John Macquarrie, Paths in Spirituality (New York: Harper \& Row, 1972), p. 40.

${ }^{25}$ Gordon Wakefield, "Spirituality," Westminster Dictionary of Christian Spirituality, ed. G. Wakefield (Philadelphia: Westminster, 1983), p. 361.

${ }^{26}$ Richard P. Hardy, "Christian Spirituality Today: Notes on its Meaning," Spiritual Life 28 (1982), 154.
} 
Williams: “And if 'spirituality' can be given any coherent meaning, perhaps it is to be understood in terms of this task: each believer making his or her own that engagement with the questioning at the heart of faith which is so evident in the classical documents of Christian belief" 27

\section{Duquoc: "the lived unity of human existence in faith.",28}

All of these definitions, no matter how vague and general they may sound, suggest that spirituality has something to do with the unification of life by reference to something beyond the individual person. While striving, perhaps in an exaggerated way, to avoid Christian exclusiveness and denominational narrowness, virtually everyone talking about spirituality today is talking about self-transcendence which gives integrity and meaning to the whole of life and to life in its wholeness by situating and orienting the person within the horizon of ultimacy in some ongoing and transforming way.

At this point we can perhaps be aided by that distinction made in the Middle Ages between the philosophical and the religious meanings of the term "spirituality." The philosophical meaning is based on the distinction between the material and the spiritual, the spiritual being understood as that capacity for self-transcendence through knowledge and love which characterizes the human being as a person. Thus, in the philosophical sense of the term, all humans are essentially "spiritual" and spirituality would be the actualization of that dimension of selfhood, that capacity for self-transcendence, in and through the establishment of personal relationships. The religious meaning of spirituality is based on the conception of what constitutes the proper and highest actualization of the human capacity for self-transcendence in personal relationship, namely, relationship with God. Spirituality, then, in its religious or theological sense, refers to the relationship between the indiviual and God pursued in the life of faith, hope, and love. The Christian meaning is a particular specification of the religious meaning. We might define Christian spirituality as that particular actualization of the capacity for self-transcendence that is constituted by the substantial gift of the Holy Spirit establishing a life-giving relationship with God in Christ within the believing community. Thus, Christian spirituality is trinitarian, christological, and ecclesial religious experience.

In short, spirituality refers to the experience of consciously striving to integrate one's life in terms not of isolation and self-absorption but of self-transcendence toward the ultimate value one perceives. If the ulti-

${ }^{2 \pi}$ Rowan Williams, Christian Spirituality: A Theological History from the New Testament to Luther and St. John of the Cross (Atlanta: John Knox, 1979), p. 1.

${ }^{28}$ Christian Duquoc, "Theology and Culture: Religious Culture, Critical Spirit, the Humility of Faith, and Ecclesiastical Obedience," tr. J. R. Foster, in Concilium 19 (New York: Paulist, 1966), 89. 
mate value is the Transcendent itself, the Deity, the spirituality is explicitly religious. But the avoidance of specifically religious language in many discussions of spirituality is an attempt to recognize that there are people whose lives are lived consciously within the horizon of ultimate concern but who do not recognize that ultimate value as God. In this sense, I do not think that the avoidance of specifically theological language necessarily involves the effort to develop a "generic" definition of spirituality. There is no such thing as generic spirituality or spirituality in general. Every spirituality is necessarily historically concrete and therefore involves some thematically explicit commitments, some actual and distinct symbol system, some traditional language, in short, a theoretical-linguistic framework which is integral to it and without which it cannot be meaningfully discussed at all. But by focusing on the common experience of integrating self-transcendence within the horizon of ultimacy one keeps open the possibility of dialogue among people of very different world views.

Among Christians, however, it seems to me that we could simplify the discussion by agreeing that the referent of the term "spirituality" is Christian religious experience as such. What this means is that spirituality, for Christians, is Christian and therefore theological considerations are relevant at every point; it is also religious, which means that it is affective as well as cognitive, social as well as personal, God-centered and other-directed all at the same time; and it is experience, which means that whatever enters into the actual living of this ongoing integrating self-transcendence is relevant, whether it be mystical, theological, ethical, psychological, political, or physical. The Transcendent who is the horizon, the focus, and the energizing source of Christian spirituality is an Other who is personal, living, and loving and is fully revealed in a human being, Jesus of Nazareth. This cannot fail to have a profound and distinguishing effect on the shape and dynamics of Christian spirituality but it is not impossible for Christians to recognize that within other religious, cultural, and historical frameworks analogous experiences of ultimate value have given rise to analogous life-integrating dynamics which can legitimately be called spiritualities.

\section{The Discipline which Studies Spirituality}

If spirituality is understood as we have suggested, certain notes will characterize the emerging discipline which purports to study spirituality. First, this discipline will be descriptive and analytic rather than prescriptive and evaluative. Whether the researcher is studying mysticism, the relation of prayer to social justice involvement, discernment of spirits, ritual, feminist religious experience, God images or any of the hundreds of other topics which are attracting the attention of students of spirituality today, the first task will be to try to understand the 
phenomenon on its own terms, that is, as it is or was actually experienced by Christians.

This leads immediately to the second characteristic, namely, the interdisciplinary approach of spirituality. Very diverse phenomena fall within the purview of spirituality and each of these presents a variety of facets. At times the appropriate methods will be historical, at other times aesthetic, at others psychological, sociological, or anthropological. And, of course, the biblical and theological questions will always need to be raised. But the time is gone when a single discipline, namely, theology, can be considered to supply the sole or even the determining approach to a given research project in the field of spirituality.

Third, spirituality seems irrevocably committed to an ecumenical and even cross-cultural approach. This greatly complicates the work of the specialist in Christian spirituality but we live in a global village which is both irreducibly pluralistic and intimately interrelated. Part of understanding any significant phenomenon is seeing how it fits into the larger picture, and for those in spirituality the larger picture is the human quest for meaning and integration of which the Christian quest is one actualization.

Fourth, spirituality is inclusive or holistic in its approach. It is not the "interior man" who seeks integration in holiness of life but the whole person, body and spirit, mind and will and emotions, individual and social, masculine and feminine. It is not only our activities but also our passivities which must be integrated, not only our achievements but also our sufferings, not only our prayer but also our struggles for justice. Again, the holistic approach makes the study of spirituality infinitely more complex than its nineteenth-century forebear but it is no longer possible for us to fragment the human person into parts and faculties, into inner and outer, into personal and social. We are all of these things at once and much of the spiritual task consists precisely in bringing this rich multi-facetedness into unity. What spirituality as life process must bring together spirituality as academic discipline must not split asunder.

Fifth, spirituality seems to be a necessarily "participant" discipline. The researcher must know the spiritual quest by personal experience if he or she is to be able to understand the phenomena of spirituality. One might be studying a spirituality quite different from one's own, but without analogous experience it is difficult to imagine how the student could come to comprehend the activities and passivities of the spiritual life. The purely disinterested phenomenological approach seems, in the very nature of the case, to be inappropriate if not impossible for spirituality.

Sixth, and as has already been suggested, spirituality studies not principles to be applied nor general classes or typical cases but concrete individuals: persons, works, events. Consequently, the student of 
spirituality is necessarily involved in what Ricoeur has called the "science of the individual" in which interpretation plays the key role and validation of interpretation through a dialectic of explanation and understanding rather than verification of repeatable scientific results is the objective. ${ }^{29}$ There can, then, be no avoiding of the truth questions about revelation, theology, creed, code, and cult. These questions can be suppressed when talking about spirituality in general, but not when the actual practice of the discipline is underway.

Seventh, spirituality, like psychology, will always have a triple objective that cannot be neatly simplified. One studies spirituality to understand spirituality; but one also studies it in order to foster one's own spirituality; and finally, one studies it in order to foster the spirituality of others. The relative importance of each of these objectives varies from student to student and from one research project to another but it is not really possible to answer once and for all the question about whether spirituality is a theoretical or a practical discipline, an objective or a subjective pursuit. It is all of these, although the emphasis varies at different moments in each project.

A final point regarding the discipline of spirituality will bring this description to a close. Spirituality is, at this point, an immature discipline. No doubt it is well past the initial stage of an emerging field during which there is little more than a felt affinity among certain scholars who sense a common interest but who are all engaged in unrelated research the results of which cannot be cumulative because they lack common vocabulary, common categories, and even organs of publication. But spirituality has not reached the point at which it is equipped with the kind of generalized theory which would constitute it a fully developed discipline recognizable as such in the halls of the academy. It is in that intermediate stage which is as awkward, but as exciting, as adolescence. People in the field today recognize each other; vocabulary is developing; the primary resources and research tools are becoming available; research and publications are increasing in quantity and quality; meetings are bringing scholars together; good students are entering the field, and, almost as important, are finding good positions when they finish their studies. The question of methodology is becoming urgent and that would seem to indicate that maturity is rapidly approaching. It is partly the issue of methodology which raised the question with which this essay is concerned: what is the relationship between spirituality and theology?

\section{Relationship of Spirituality to Theology}

On the basis of the foregoing we are in a position to suggest at least a tentative answer to the question with which we began: what is the

${ }^{29}$ See Paul Ricoeur, Interpretation Theory: Discourse and the Surplus of Meaning (Fort Worth: Texas Christian University Press, 1976), p. 79. 
relationship between spirituality and theology. For our purposes, I am presupposing that we are talking about Christian spirituality and Christian theology. It should be clear by now that this question actually has two foci which must be considered separately. We must inquire, first, into the relationship between theology and spirituality as lived Christian experience, and, second, into the relationship between spirituality as an academic discipline and theology which is also an academic discipline.

\section{Lived Spirituality and Theology}

As the history of the Church makes abundantly clear, spirituality as lived religious experience is prior to theology, both ontologically and psychologically. The New Testament itself bears witness to this fact. Christians, because of the experience they had with the historical Jesus and especially because of the resurrection experience, began to reflect theologically, in light of both Old Testament revelation and available philosophical frameworks, on his identity and mission. Later experience of conflicting interpretations of the Christ-event led to theological refinements, while subsequent experience of Christians interacting with diverse historical-cultural circumstances raised new problems and suggested new answers which required to be integrated into the already elaborated synthesis. Over the span of centuries the intellectual edifice of Christian theology came into being and reached a peak of integration and clarity in the thirteenth century.

The medieval synthesis held well until the middle of the twentieth century when the world-shattering events of two world wars, the technological revolution, liberation movements of all kinds, an explosion of knowledge, and rapid developments in philosophy, the humanities, the personality and social sciences brought its comprehensive hold on the Christian mind and imagination to an end. Theology today is both critical and pluralistic and it seems unlikely that it will settle into a new "perennial" form any time in the foreseeable future. But this thumbnail sketch suffices to illustrate our point, namely, that it is spirituality, that is, Christian experience of living the faith in various times, places, cultures and in the midst of various issues, problems, and triumphs that generates theology, not, as the nineteenth-century theologians thought, theology which generates spirituality.

However, by that curious dialectic observable in other fields as well, once theology has arisen in response to and as an explicit articulation of Christian religious experience, it comes to have both the ability and the responsibility to criticize spirituality. Just as it is literature which generates literary criticism but the latter which then operates to sift the good from the bad, to analyze and explicate the good, and even to stimulate artists in their work, so theology generated by spirituality is the primary 
evaluator and critic of spirituality. It is theology which renders judgment on the adequacy of a particular spirituality to the Gospel and Tradition; theology which challenges partial or one-sided approaches; theology which defends the prophetic and charismatic; theology which finally helps the believer to understand his or her experience and by understanding to appropriate it more deeply and live it more fully. It must never be forgotten that, despite this important role, theology is a servant of Christian experience, not its master. Just as the biblical scholar must never presume to fetter the Word of God with the human bonds of exegesis, so the theologian must not presume to manufacture or to control the work of the Spirit in the churches. But without the service of the biblical scholar much in scripture would remain unintelligible, and without the service of the theologian spirituality could degenerate into enthusiastic chaos, dangerous aberrations, or anemia.

It must also be kept in mind that, while theology is the most important single discipline at the service of spirituality, it is by no means the only one. The spiritual life, as has been said, embraces the whole of human experience within the horizon of ultimate concern. Consequently, the personality sciences, the social sciences, literary and aesthetic disciplines, history, comparative religion, and a variety of other fields of study are important to the understanding and to the living of Christian religious experience.

\section{The Academic Disciplines of Spirituality and Theology}

The second question, that of the place of this new field of study, Christian spirituality, in the academic world is receiving a good deal of attention today, and necessarily so. Does this field, because of its interdisciplinary, humanistic, and cross-cultural character, belong in the university; or, because of its necessarily concrete confessional character, in the theological school; or, because of its orientation toward practice, in the ministerial school? And even if it is placed in the theology department should it be accorded autonomous status as a distinct discipline, an equal partner alongside biblical studies and systematic theology, or should it be diffused among the older disciplines as the proper horizon for or a focus of interest in the study of all theology?

First of all, we must clarify the term "theology" as it is used in the academy. Often "theology" is used as an umbrella term for all of the sacred sciences, that is, for all religious studies carried out in the context of explicit reference to revelation and explicitly affirmed confessional commitment. Thus, under the heading of theology one finds systematic theology including foundational theology, theology of God, ecclesiology, christology, and eschatology; moral theology including both general and special, personal and social ethics; and, finally, church history and biblical studies. A theology department or school might also include 
practical and/or mixed disciplines such as religious education, pastoral counseling, liturgy, homiletics, and ministry.

When theology is understood in this manner the discipline of Christian spirituality belongs under the heading of theology as one field of revelation-related, confessionally committed scholarly endeavor, namely, the field that studies Christian religious experience as such in an interdisciplinary way. As in other theological disciplines today the edges of the field are often "soft." Several of the once-designated "secular" disciplines are an integral part of the studies carried out in the field of spirituality. But this does not cancel the central fact that the essential work of spirituality as a field of study is theological in this broad sense of the term.

However, there is a second and narrower understanding of theology. In this second sense theology denotes systematic theology and moral theology, the two major fields which have, since the Middle Ages, organized the scientific study of the faith. Taken in this restricted sense, theology does not include biblical studies, church history, or the practical and mixed disciplines. And by the same token it also does not include spirituality. This amounts to a denial of the classical position that spirituality is a dependent of dogmatic theology and/or a subdivision of moral theology. Although spirituality as the lived experience of the faith is indeed the horizon within which all theological work must be done since theology arises from and is oriented toward that lived experience of the Christian community, spirituality as an academic discipline has its own subjects of study, its own methods and approaches, and its own objectives, just as do biblical studies, church history, and the practical theological disciplines.

It suffices to list the subjects of some recent doctoral dissertations in spirituality to be convinced that the subject matter of spirituality is distinct from, however intimately related to, that of systematic and moral theology. Subjects such as mysticism, prayer, discernment, spiritual friendship, spiritual direction, the relation of prayer to social justice, schools of spirituality, the spirituality of certain great figures, the relation of analogous spiritual phenomena and/or practices across confessional or cultural boundaries, the body/spirit dialectic in the spiritual life, the patterns and dynamics of spiritual growth, the interaction of culture and faith in the development of the spiritual life, the meaning of sanctity, the relationship of psychological maturity to spiritual development, biblical spirituality, liturgical spirituality, the distinctiveness of feminine religious experience, and the like are all subjects the study of which has an important theological moment but which cannot be adequately investigated as purely theological problems in the narrower sense of the term "theology."

Because of the very nature of the phenomena which spirituality studies its methods and approaches are irreducibly pluralistic and thor- 
oughly interdisciplinary. Most research projects in spirituality will involve biblical, historical, theological, social, psychological, aesthetic, and comparative approaches. The use of these disciplines will be governed by the methods appropriate to these disciplines themselves but the underlying and guiding philosophical presuppositions are usually hermeneutical since the fundamental problem in spirituality is always that of interpretation of particulars in order to understand the experience which comes to expression therein.

Finally, the objectives of the discipline of spirituality are distinct and peculiar to the field. As has been mentioned, the objectives are always simultaneously theoretical and practical in a way analogous to the objectives of psychology or art. The objective is not so much double as dual, the theoretical and practical dimensions being in a constant dialectical relationship throughout the study. It may well be that spirituality as a discipline will have to address in a self-conscious way, in the not too distant future, the question of what effect this dual character has on the nature and quality of research in the field. Students in the field of spirituality neither want to nor can be "objective" in the sense of personally uninvolved in their subject matter (if, indeed, any researcher is purely "objective" in any field!). There is no "factoring out" of personal questions and ultimate self-implication in results. In this sense, the field resembles the arts more than the sciences. It is certainly a humanistic rather than an exact or "hard" science. In any case, there seems to me to be little question that the objectives of the study of spirituality are distinct from, although not unrelated to, those of the classical theological disciplines.

\section{Conclusion}

By a long and tortuous path we have come to a tentative response to our original question: what is the relationship between spirituality and theology? We have traced the trajectory of a long and troubled relationship which began serenely in a peaceful unity. But, as so often happens, the two partners in the relationship matured, each at a different rate of speed and in different ways. This resulted in a domination, within the relationship, of spirituality by theology. But in recent decades this well-behaved and subordinate partner has emerged as an autonomous dialogue partner demanding independence for the sake of mature interdependence. Some will say, not entirely without basis, that spirituality, freed from its subordination to theology, is wandering abroad in strange places and experimenting with strange relationships. Some think the solution is to restore the order of the theological household by either reasserting theology's proper headship or expelling the wanderer from the house altogether. Those who know the field of spirituality are certain that neither solution is appropriate. Spirituality has grown up and is 
here to stay. It must make its own alliances, and its own mistakes, but it belongs in the household of theology in the broad sense of that term. It is no longer a mindless subordinate controlled by theology nor a pedestaled idol, lovely to look at but useless in discussion. Spirituality is that field-encompassing field ${ }^{30}$ which studies Christian religious experience as such. And there is, when all is said and done, almost nothing whose study is more important than spirituality for us who are called to integrate our lives in self-transcending faith, hope, and love through and in the Spirit of Jesus the Christ.

${ }^{30}$ See, on the nature of the field-encompassing field, Van A. Harvey, The Historian and the Believer: The Morality of Historical Knowledge and Christian Belief (Philadelphia: Westminster, 1966), pp. 38-67, esp. 54-59. 